\title{
Sweating Fever
}

National Cancer Institute

\section{Source}

National Cancer Institute. Sweating Fever. NCI Thesaurus. Code C35052.

A febrile response accompanied by diaphoresis. 